\title{
Mirosław Wincenciak
}

\section{FUNKCJE TERMINÓW MATERIALNYCH \\ W PRAWIE BUDOWLANYM \\ PRÓBA REKONSTRUKCJI DÓBR PRAWEM CHRONIONYCH}

\section{Wstęp}

Dobra prawem chronione można definiować z następujących punktów widzenia: zasad i wartości istotnych dla danej gałęzi prawa; celów i funkcji aktu normatywnego ${ }^{1}$; dóbr chronionych normami prawnymi ustanowionymi w akcie normatywnym. Można określać zatem dobra chronione jako właściwe dla danej gałęzi prawa oraz będące ich uszczegółowieniem dobra chronione na podstawie poszczególnych aktów normatywnych i konkretnych norm prawnych. Powyższe wynika z tego, że każda regulacja prawna służy jakiemuś celowi, który chce osiągnąć prawodawca. Założenia tego celu można wywieść, w przypadku niektórych ustaw, a także aktów prawa Unii Europejskiej, z preambuł do tych aktów, jak również z dokumentacji dotyczącej przebiegu prac legislacyjnych nad nimi. Wypowiedzi twórców aktu czy gremiów współdziałających przy jego tworzeniu wskazują na cele prawodawcy. Cel regulacji ustala się także w procesie wykładni i stosowania norm zawartych w akcie normatywnym. Dekodowane normy prawne, ich wykładnia, wzajemne relacje między normami stanowią o przedmiocie regulacji i funkcjach norm - dają wyobrażenie o dobrach i wartościach, które chce chronić prawodawca. Jednakże cele zamierzone przez prawodawcę, artykułowane w preambułach do aktów oraz w wypowiedziach ich twórców - z uwagi na ułomność regulacji prawnej - mogą być trudne do osiągnięcia bądź niewykonalne.

Truizmem jest twierdzenie, że upływ czasu ma znaczenie we wszystkich stosunkach społecznych regulowanych przepisami prawa. Istotą upływu czasu w każdej gałęzi prawa jest wiązanie skutków prawnych z tą okolicznością w mniejszym lub większym zakresie. Upływ czasu może niweczyć określone

* Dr, Zakład Prawa Ochrony Środowiska i Nauki Administracji Publicznej, Wydział Prawa Uniwersytetu w Białymstoku.

${ }^{1} \mathrm{~Np}$. cel przyświecający ustawie o wychowaniu w trzeźwości i przeciwdziałaniu alkoholizmowi wynika z samej nazwy ustawy i preambuły do tej ustawy. 
prawa lub kreować nowe. Podobnie rzecz się ma z ustawą Prawo budowlane ${ }^{2}$. W ustawie tej prawodawca ustanowił szereg terminów, których upływ może niweczyć uprawnienie do dokonania określonych czynności procesowych, powodować utratę prawa bądź wreszcie utratę kompetencji do działania. Bliższa analiza regulacji skłania do wniosku, że twórcy ustawy, jak się wydaje, sami nie byli przekonani co do funkcji i charakteru niektórych terminów. Budzi też wątpliwości długość niektórych terminów. Wydaje się, że nie zawsze jest ona adekwatna do charakteru i rodzaju stosunku społecznego, którego dotyczy oraz celu zamierzonego przez prawodawcę. W artykule została podjęta analiza wybranych terminów, określanych przez judykaturę jako materialne, i próba wskazania ich funkcji z punktu widzenia przedmiotu oraz celu regulacji. Innymi słowy, zamierzam poczynić refleksje nad wartościami i dobrami, które prawodawca chroni, ustanawiając je w ustawie.

\section{Terminy materialne i procesowe w wybranych gałęziach prawa}

Na gruncie prawa cywilnego z upływem czasu wiązane są różne konsekwencje prawne. Na przykład posiadanie samoistne nieruchomości skutkuje nabyciem jej własności (zasiedzeniem) przez posiadacza samoistnego i w konsekwencji utratą prawa własności przez dotychczasowego właściciela. $Z$ kolei w prawie zobowiązań upływ czasu może powodować przekształcenie wierzytelności z kontraktu w zobowiązanie naturalne.

$\mathrm{Na}$ gruncie prawa prywatnego wprowadzenie terminu przedawnienia uzasadniania się jego wychowawczą rolą, zmusza on bowiem do szybkiej reakcji w związku z naruszeniem prawa ${ }^{3}$. Wskazuje się także, że określenie terminów działa dyscyplinująco na uczestników obrotu cywilnego, wywierając na nich nacisk, aby terminowo dochodzili swoich roszczeń ${ }^{4}$. Odnośnie do przedawnienia roszczeń wskazuje się, że nie może trwać ono wiecznie, gdyż godziłoby to w porządek prawny, a także podważałoby ład w stosunkach gospodarczych i społecznych ${ }^{5}$. Jako uzasadnienie przedawnienia podaje się również czynnik upływu czasu jako destruktora powodującego trudności dowodowe czy też trudności egzekucyjne. Wskazuje się ponadto, że długotrwałość określonego stanu faktyczne-

2 Ustawa z 7 lipca 1994 r. - Prawo budowlane (tekst jedn. Dz. U. z 2010 r., nr 243, poz. 1623 ze zm., dalej: ustawa lub p.b. ).

3 T. Zieliński, Przedawnienie i terminy zawite $w$ prawie pracy jako problem kodyfikacyjny, „Państwo i Prawo” 1970, nr 8-9, s. 253.

${ }^{4}$ A. Szpunar, Nadużycie prawa $w$ dziedzinie przedawnienia, „Ruch Prawniczy, Ekonomiczny i Socjologiczny" 1969, nr 4, s. 43.

5 A. Brzozowski, Nowa regulacja przedawnienia w prawie cywilnym, „Państwo i Prawo” 1992, nr 3 . 
go winna być istotnym czynnikiem legalizującym ten $\operatorname{stan}^{6}$. Według T. Pałdyny przedawnienie pełni funkcje: ochronną, oczyszczającą, stabilizacyjną i animacyjną $^{7}$. Autor wskazuje, że jednym z celów przedawnienia jest ochrona dłużnika. Ochronę tę uzasadniają w szczególności trudności dowodowe, jakie mają miejsce $\mathrm{w}$ procesie o roszczenia sprzed lat ${ }^{8}$. $\mathrm{Z}$ kolei funkcję oczyszczającą autor określa jako pozbawienie obrotu z pewnych zaszłości. Utrzymywanie niezrealizowanych przez lata zobowiązań nie leży w interesie wymiaru sprawiedliwości. Wszczynanie procesów po latach, $\mathrm{z}$ uwagi na trudności dowodowe, prowadzić może do rozstrzygnięć przypadkowych, a nie do wymierzania sprawiedliwości ${ }^{9}$. Jeśli chodzi o funkcję stabilizacyjną, to według badacza przedawnienie ma za zadanie stabilizować istniejące stosunki. Potrzeba ta (stabilizacji stosunków) szczególnie ważna jest w obrocie gospodarczym ${ }^{10}$. Funkcja animacyjna przedawnienia w prawie cywilnym ma prowadzić do usprawnienia obrotu. Oznacza pobudzenie wierzyciela do szybkiej realizacji roszczeń i ma na celu ożywianie obrotu gospodarczego ${ }^{11}$.

$\mathrm{Z}$ kolei na gruncie prawa karnego przedawnienie definiowane jest jako wyłączenie lub ograniczenie reakcji karnej z powodu upływu czasu. Wśród przyczyn przedawnienia wskazuje się osłabienie, a w konsekwencji brak celowości reakcji karnej $^{12}$. Uzasadnienia zatem przedawnienia należy poszukiwać $\mathrm{w}$ celach kary. Upływ czasu nie daje możliwości oddziaływania karą zapobiegawczo i wychowawczo wobec skazanego czy też w zakresie kształtowania świadomości prawnej społeczeństwa. $Z$ upływem lat od popełnienia przestępstwa zazwyczaj słabnie lub zanika potrzeba zadośćuczynienia społecznemu poczuciu sprawiedliwości ${ }^{13}$. W obecnym ujęciu kodeksowym przedawnienie ma charakter stricte materialny, kodeks wskazuje dwa rodzaje przedawnienia: karalności ${ }^{14}$ oraz przedawnienie wykonania kary ${ }^{15}$.

Jeśli chodzi o terminy o charakterze procesowym, to w zasadzie w każdej gałęzi prawa istota tych terminów jest podobna. Terminy procesowe dzieli się między innymi na terminy: do dokonania czynności procesowej przez podmiot sprawujący jurysdykcję; terminy dokonania czynności przez stronę; terminy dokonania czynności przez innych uczestników postępowania jurysdykcyjnego.

${ }^{6}$ B. Kordasiewicz, [w:] Z. Radwański (red.), System prawa prywatnego, t. 2, Prawo cywilne - część ogólna, Warszawa 2002, s. 539-540; por. też A. Szpunar, op. cit.

7 T. Połdyna, Przedawnienie w polskim prawie cywilnym, Warszawa 2009, s. 61.

8 Ibidem, s. 61.

9 Ibidem, s. 63-64.

10 Ibidem, s. 65.

11 Ibidem. S. 67.

12 M. Cieślak, Polskie prawo karne. Zarys systemowego ujęcia, Warszawa 1994, s. 482.

13 A. Zoll, [w:] K. Buchała, A Zoll, Kodeks karny. Część ogólna, Kraków 2000, s. 587.

14 Art. 101 k.k.

15 Art. 102 k.k. 
Upływ terminu procesowego do dokonania czynności procesowej skutkuje wygaśnięciem tego uprawnienia. Złożenie środka zaskarżenia z uchybieniem terminowi powoduje odmowę merytorycznego rozpoznania sprawy przez właściwy organ albo sąd. Terminy procesowe ustanowione dla dokonania czynności przez stronę w kodeksie postępowania administracyjnego są terminami przywracalnymi, chyba że kodeks ten stanowi inaczej ${ }^{16}$.

Jeśli chodzi o rozróżnienie terminów procesowych od materialnych, to wielokrotnie na gruncie prawa podkreślano, że o charakterze terminu nie może przesądzać jedynie jego usytuowanie $\mathrm{w}$ akcie prawodawczym uznawanym za regulację materialnoprawną czy regulację procesową, gdyż takie podziały są nieostre i umowne. Wskazać można, że w ustawach uznawanych za procesowe znajdują się normy materialne ${ }^{17}$, a z kolei w ustawach dotyczący materii prawa występują przykłady norm prawa procesowego. O charakterze terminu przesądza istota regulacji prawnej danego stosunku społecznego.

\section{Upływ czasu w prawie administracyjnym}

Dla właściwego ukształtowania modelu określonej regulacji w sferze prawa materialnego znaczenie ma zidentyfikowanie celów i funkcji regulacji prawnej $\mathrm{z}$ uwzględnieniem idei i zasad przyjętych $\mathrm{w}$ danej gałęzi prawa, wyinterpretowanych z Konstytucji oraz z systemu prawa. Racje, dla których prawodawca zastosował terminy do dokonania czynności prawnych oraz określił ich długość, nierzadko są trudne do uchwycenia. Specyfika prawa administracyjnego oraz obszerność i różnorodność stosunków społecznych regulowanych metodą administracyjno-prawną nie zawsze dają jednoznaczne odpowiedzi co do konsekwencji prawnych upływu czasu i ich funkcji w prawie administracyjnym. Jak wynika z bardzo skrótowego przedstawienia konsekwencji upływu terminów w prawie cywilnym i w prawie karnym, funkcje upływu czasu w obu tych gałęziach prawa są diametralnie odmienne. $\mathrm{Z}$ uwagi na swoistość regulacji prawa administracyjnego trudno czynić użytek $\mathrm{z}$ dorobku doktryny wspomnianych gałęzi prawa w odniesieniu do charakteru i funkcji terminów materialnych określonych w przepisach prawa administracyjnego.

$\mathrm{Z}$ punktu widzenia przedmiotu regulacji administracyjnoprawnej, konsekwencje prawne upływu czasu mogą dotyczyć sytuacji prawnej podmiotów administrowanych i podmiotów administrujących. Zatem problematyka konsekwencji upływu czasu może być rozpatrywana przynajmniej w dwóch płaszczyznach. Po pierwsze, jako upływ czasu skutkujący utratą kompetencji po stronie organu do wydania aktu lub podjęcia czynności oraz po drugie, poprzez upływ czasu

${ }^{16}$ B. Adamiak, [w:] B. Adamiak, J. Borkowski, Kodeks postępowania administracyjnego. Komentarz, Warszawa 3, s. 317-318.

17 Za taką uznaje się w orzecznictwie por. art. 28 k.p.a. 
jako konsekwencję prawną dotyczącą podmiotów administrowanych. W ostatnim przypadku upływ czasu może być negatywną przesłanką do uzyskania czy zachowania prawa przez podmiot administrowany. Ponadto może także skutkować bądź zachowaniem prawa przez podmiot administrowany, bądź też niepogorszeniem jego sytuacji prawnej.

Z pierwszą sytuacją będziemy mieli do czynienia na przykład, gdy chodzi o termin do wydania rozstrzygnięcia nadzorczego przez organ nadzoru ${ }^{18}$. Przykładem drugiej sytuacji - utraty prawa, korzyści lub roszczenia - może być upływ terminu do dochodzenia roszczeń przez funkcjonariusza policji z tytułu świadczeń związanych ze stosunkiem zatrudnienia ${ }^{19}$. Z kolei przykładem trzeciej kategorii sytuacji - uzyskania swoistej gwarancji prawnej niepogarszania sytuacji podmiotu administrowanego - może być przedawnienie należności z tytułu nienależnie pobranych świadczeń rodzinnych ${ }^{20}$. Z pewnym uproszczeniem można stwierdzić, że upływ terminu skutkujący utratą kompetencji po stronie organu do działania w zakresie nałożenia obowiązku prawnego lub stwierdzenia jego istnienia, skutkuje swoistym refleksem w stosunku do podmiotu administrowanego. W jakimś sensie podmiot administrowany uzyskuje korzyść. Niemożność bowiem działania podmiotu administrującego oznacza brak reakcji prawnej w sprawie obiektywnie wymagającej takiego działania, ale już niedopuszczalnej z uwagi na upływ czasu. Dobitnym przykładem takiej sytuacji może być art. 145 ust. 2 ustawy o gospodarce nieruchomościami, w którym określony jest termin do ustalenia przez organ opłaty adiacenckiej. Upływ tego terminu oznacza, że organ traci kompetencję do określenia tej opłaty, a właściciel nieruchomości uzyskuje gwarancję niewymierzenia tej opłaty ${ }^{21}$.

18 Por. art. 90 ust. 1 zdanie 2 ustawy z dnia 8 marca 1990 r. o samorządzie gminnym (tekst jedn. Dz. U. z 2001 r., nr 142, poz.1591 ze zm.); art. 79 ust. 1 zdanie 2. ustawy z dnia 5 czerwca 1998 r. o samorządzie powiatowym (tekst jedn. Dz. U. z 2001 r., nr 142, poz.1592 ze zm.); art. 82 ust. 1 zdanie 2. ustawy z dnia 5 czerwca 1998 r. o samorządzie województwa (tekst jedn. Dz. U. z 2001 r., nr 142, poz. 1590 ze zm.)

19 Por. np. art. 107 ustawy z dnia 6 kwietnia 1990 r. o policji (tekst jedn. Dz. U. z 2011 r. nr 287, poz. 1687 ze zm.) „1. Roszczenia z tytułu prawa do uposażenia i innych świadczeń oraz należności pieniężnych ulegają przedawnieniu z upływem 3 lat od dnia, w którym roszczenie stało się wymagalne. 2. Organ właściwy do rozpatrywania roszczeń może nie uwzględnić przedawnienia, jeżeli opóźnienie w dochodzeniu roszczenia jest usprawiedliwione wyjątkowymi okolicznościami. 3 . Bieg przedawnienia roszczenia z tytułu uposażenia i innych świadczeń oraz należności pieniężnych przerywa: 1) każda czynność przed kierownikiem jednostki organizacyjnej podległej ministrowi właściwemu do spraw wewnętrznych, właściwym do rozpatrywania roszczeń, podjęta bezpośrednio w celu dochodzenia lub ustalenia albo zaspokojenia roszczenia; 2) uznanie roszczenia".

${ }^{20}$ Art. 30 ust. 3 ustawy z 28 listopada 2003 r. o świadczeniach rodzinnych (tekst jedn. Dz. U. z 2006 r., nr 139, poz. 992 ze zm.) stanowi „Należności z tytułu nienależnie pobranych świadczeń rodzinnych ulegają przedawnieniu z upływem 3 lat, licząc od dnia, w którym decyzja ustalająca te należności stała się ostateczna".

${ }^{21} \mathrm{Na}$ temat obliczania terminów do wymierzenia tej opłaty por. uchwałę 7 sędziów NSA z 27 lipca 2009 r., I OPS 4/09, ONSA i WSA 2009/5/84; na temat skutków materialnych i procesowych 


\section{Terminy w prawie budowlanym}

W ustawie Prawo budowlane prawodawca wielokrotnie posługuje się pojęciem terminu, łącząc z jego upływem określone konsekwencje prawne ${ }^{22}$. Zgodnie z systematyką przytoczoną powyżej, terminy w prawie budowlanym można podzielić na terminy prawa procesowego i terminy prawa materialnego. Wśród tych pierwszych można wyróżnić terminy do podjęcia czynności prawnych przez: organ, strony postępowania administracyjnego czy innych jego uczestników. Jak już wspomniałem, terminy materialne - to terminy, które zakreślają przedział czasu dla organów administracji budowlanej do podjęcia czynności prawnych, a także terminy do podjęcia działań przez podmioty administrowane, których upływ w jakimś sensie niweczy prawo tych podmiotów albo gwarantuje im niepogorszenie ich sytuacji prawnej.

terminów decyzji por. Z.R. Kmiecik, Strona jako podmiot oświadczeń procesowych w postępowaniu administracyjnym, Warszawa 2008, s. 268.

22 Por. np.: obowiązek właściciela lub zarządcy budynku uzyskania świadectwa charakterystyki energetycznej budynku i przekazania jego kopii nieodpłatnie właścicielowi lokalu mieszkalnego lub osobie, której przysługuje spółdzielcze własnościowe prawo do lokalu, w terminie nie dłuższym niż 6 miesięcy od dnia złożenia przez niego wniosku w tej sprawie - art. 5 ust. 5a; prawo zwrócenia się do ministra właściwego do spraw budownictwa, lokalnego planowania i zagospodarowania przestrzennego oraz mieszkalnictwa, w terminie 2 miesięcy od dnia doręczenia decyzji, $\mathrm{z}$ wnioskiem o ponowne rozpatrzenie sprawy - art. $5^{1}$ ust. 6; wskazanie w zgłoszeniu terminu rozpoczęcia robót budowlanych - art. 30 ust. 2; określenie w postanowieniu terminu do uzupełnienia brakujących dokumentów, a w przypadku ich nieuzupełnienia - wnosi sprzeciw, w drodze decyzji - art. 30 ust. 2; 30-dniowy termin do wniesienia sprzeciwu w drodze decyzji - art. 30 ust. 5; nałożenie postanowieniem obowiązku usunięcia wskazanych nieprawidłowości i określenie terminu ich usunięcia - art. 35 ust. 3; określenie 65-dniowego terminu do wydania decyzji w sprawie pozwolenia na budowę, przekroczenie tego terminu zagrożone jest karą w wysokości 500 zł za każdy dzień zwłoki - art. 35 ust. 6; 30-dniowy termin do zajęcia stanowiska przez wojewódzkiego konserwatora zabytków w sprawie wniosku o pozwolenie na budowę lub rozbiórkę obiektów budowlanych, o których mowa w ust. 3; niezajęcie stanowiska w tym terminie uznaje się jako brak zastrzeżeń do przedstawionych we wniosku rozwiązań projektowych - art. 39 ust. 4; rozstrzygnięcie w formie decyzji przez właściwy organ, w terminie 14 dni od dnia złożenia wniosku, o niezbędności wejścia do sąsiedniego budynku, lokalu lub na teren sąsiedniej nieruchomości - w przypadku nieuzgodnienia pomiędzy stronami warunków wejścia do sąsiedniego budynku lub lokalu - art. 47 ust. 2; ustalenie, w wyznaczonym terminie, wymagań dotyczących niezbędnych zabezpieczeń budowy oraz nałożenie obowiązku przedstawienia, w wyznaczonym terminie, dokumentów prawem przewidzianych - art. 48 ust. 3; możliwość nałożenia w postanowieniu o wstrzymaniu robót budowlanych obowiązku przedstawienia, w terminie 30 dni od dnia doręczenia postanowienia, inwentaryzacji wykonanych robót budowlanych lub odpowiednich ocen technicznych bądź ekspertyz - art. 50 ust. 3; utrata ważności postanowienie o wstrzymaniu robót budowlanych traci ważność po upływie 2 miesięcy od dnia doręczenia, chyba że w tym terminie zostanie wydana decyzja - art. 50 ust. 4; prawo do przystąpienia do użytkowania obiektu budowlanego, na którego wzniesienie jest wymagane pozwolenie na budowę, po zawiadomieniu właściwego organu o zakończeniu budowy, jeżeli organ ten, $\mathrm{w}$ terminie $21 \mathrm{dni}$ od dnia doręczenia zawiadomienia, nie zgłosi sprzeciwu w drodze decyzji - art. 54 . 
Nieskorzystanie, z różnych przyczyn, przez organ z przysługującej mu w określonym czasie kompetencji, skutkuje swego rodzaju refleksem po stronie podmiotu administrowanego - prawem do niepogorszenia jego sytuacji. Jako przykłady terminów prawa materialnego wskazywane są: art. 50 ust. 4 p.b. stanowiący o utracie ważności postanowienia z upływem 2 miesięcy od daty jego doręczenia ${ }^{23}$ czy terminy do wniesienia sprzeciwu przez organy, określone $\mathrm{w}$ art. 30 ust. 5p.b. ${ }^{24} \mathrm{i}$ art. 54 p.b. ${ }^{25}$.

Upływ pierwszego ze wspomnianych terminów - w przypadku niewydania w tym terminie decyzji przez organ nadzoru budowlanego - powoduje utratę mocy wiążącej postanowienia ${ }^{26}$. Oznacza to, że inwestor ma prawo do kontynuowania robót budowlanych wstrzymanych postanowieniem. Nakazy i zakazy wynikające $\mathrm{z}$ postanowienia tracą moc $\mathrm{z}$ upływem wspomnianego terminu. Jest on zatem terminem obowiązywania postanowienia w obrocie prawnym, a warunkiem prowadzenia dalszych procedur administracyjnych jest wydanie decyzji, o której mowa w art. 50a pkt 2 albo w art. 51 ust. 1. przed upływem 2 miesięcy od dnia doręczenia postanowienia. Wskazuje się, że termin, o którym mowa w art. 50 ust. 4 p.b. jest terminem prawa materialnego, co oznacza, że pojęcie „wydanie decyzji” należy rozumieć jako jej podjęcie, a nie doręczenie ${ }^{27}$.

W doktrynie określa się, że upływ czasu, na który został akt wydany, a więc nadejście terminu końcowego, ma charakter zdarzenia przyszłego i nieuniknionego oraz że powoduje wygaśnięcie aktu. Upływ terminu działa automatycznie: akt wygasa. Wraz z nadejściem terminu końcowego decyzja przestaje obowiązywać, wygasa per se i nie ma potrzeby ani też uzasadnienia stwierdzanie jej wygaśnięcia ${ }^{28}$.

W judykaturze wskazuje się, że po upływie terminu ważności postanowienia o wstrzymaniu robót budowlanych, postanowienie to traci swoją moc prawną i dlatego też nie jest dopuszczalna jego weryfikacja, ponieważ nie ma możliwości weryfikacji aktu, który nie występuje już w obrocie prawnym. Zatem gdy w chwili orzekania przez organ drugiej instancji zaskarżone postanowienie nie występuje już w obrocie prawnym, to postępowanie drugoinstancyjne staje się bezprzedmiotowe. Organ drugiej instancji traci kompetencję do wypowiadania się w przedmiocie postanowienia, które nie występuje już w obrocie prawnym; nie może

23 Tak NSA w wyroku z 11 stycznia 2012 r., II OSK 2003/10, LEX nr 1121189.

${ }_{24}$ Tak np. WSA w wyrokach: z dnia 12 kwietnia 2012 r., II SA/Ke 55/12, LEX nr 1170776; 28 marca 2012 r., II SA/Rz 115/12, LEX nr 1138766; z dnia 26 marca 2012 r., II SA/Kr 47/12, LEX nr 1138599.

${ }_{25}$ Por. np. wyroki: NSA z 18 października 2011 r. II OSK 1447/10, LEX nr 1151879; NSA z 12 grudnia 2008 r., II OSK 1588/07, LEX nr 515983.

${ }^{26}$ Por. wyrok WSA w Krakowie z 12 października 2009 r., II SA/Kr 988/09, LEX nr 573774.

27 Tak NSA w wyroku 11 stycznia 2012 r., II OSK 2003/10, LEX nr 1121189.

28 T. Woś, Moc wiążaca aktów administracyjnych w czasie, Warszawa 1978, s. 165, tenże, Termin, warunek i zlecenie w prawie administracyjnym, „Państwo i Prawo” 1994, nr 6, s. 27. 
go z tego właśnie względu ani utrzymać w mocy, ani uchylić. W takiej sytuacji uzasadnione jest wydanie rozstrzygnięcia w przedmiocie umorzenia postępowania zainicjowanego zażaleniem na postanowienie organu pierwszej instancji ${ }^{29}$. W judykaturze podnosi się także, że upływ terminu ważności wspomnianego postanowienia nie stanowi przeszkody w dokonaniu kontroli jego legalności przez sąd administracyjny. Podkreśla się, że należy odróżniać zagadnienie ważności postanowienia wydanego na podstawie art. 50 ust. 1 p.b. od oceny legalności tego rozstrzygnięcia, której na skutek wniesionej skargi może dokonać tylko sąd administracyjny ${ }^{30}$.

Termin wymieniony w art. 50 ust. 4 p.b. ma niewątpliwie charakter gwarancyjny w stosunku do strony-podmiotu, wobec którego toczy się postępowanie naprawcze. Jego upływ oznacza brak możliwości reakcji prawnej po stronie organu w postaci kontynuowania procedury, o której mowa w art. 50a pkt 2 albo w art. 51 ust. 1. Podmiot ten nie jest już związany nakazami i zakazami wynikającymi z wydanego postanowienia. Prawodawca wiąże skutek utraty ważności tego postanowienia $\mathrm{z}$ upływem terminu od daty doręczenia tego postanowienia. Postanowienie wydawane w trybie art. 50 ust. 4 jest doręczane oprócz sprawcy naruszenia prawa, które było powodem wszczęcia postępowania, także innym stronom. Zatem termin dwóch miesięcy od dnia doręczenia postanowienia może upływać w różnych datach w zależności od daty skutecznego doręczenia postanowienia każdej ze stron. Wydaje się jednak być dość oczywiste, że upływ dwumiesięcznego terminu do wydania decyzji, o której mowa w art. art. 50a pkt 2 i art. 51 ust. 1, następuje z upływem terminu liczonego w stosunku do podmiotu, wobec którego orzeczono o wstrzymaniu wykonywania dalszych robót. Doręczenie tego postanowienia pozostałym stronom w innych terminach nie ma znaczenia dla ustalenia daty utraty jego ważności. Doręczenie postanowienia będzie skuteczne, jeżeli nastąpi ono zgodnie z regułami k.p.a.

Podzielam pogląd NSA wyrażony w wyroku z 11 stycznia 2012 r., II OSK $2003 / 10^{31}$, że bieg terminu rozpoczyna się od doręczenia postanowienia organu podmiotowi zobowiązanemu do wstrzymania robót budowlanych, natomiast jego upływ następuje w przypadku niewydania w tym terminie decyzji przez organ. Doręczenie postanowienia organu oprócz skutku materialnoprawnego w postaci rozpoczęcia biegu terminu do wydania decyzji administracyjnej wywołuje również skutek procesowy w postaci rozpoczęcia biegu terminu do wniesienia zażalenia na to postanowienie do organu odwoławczego. Zdarzeniem prawnie doniosłym dla rozpoczęcia biegu tego terminu jest więc doręczenie postanowienia, a podmiotem kreującym ten termin jest organ nadzoru budowlanego, który wydaje to postanowienie.

${ }^{29}$ Tak np. WSA w Krakowie w wyroku z 12 października 2009 r., II SA/Kr 988/09, LEX nr 573774.

${ }^{30}$ Por. wyrok NSA z 26 sierpnia 2009 r., II OSK 1304/08; LEX nr 526348.

31 LEX nr 1121189. 
Jak już wspomniałem, upływ ważności postanowienia na etapie postępowania odwoławczego uzasadnia umorzenie postępowania w sprawie. Jak się wydaje, nie ma jednak przeszkód, by w stosunku do postanowienia, które już nie obowiązuje $\mathrm{w}$ obrocie prawnym, prowadzić postępowanie $\mathrm{w}$ przedmiocie stwierdzenia jego nieważności - zgodnie z art. 156 - art. 158 k.p.a. w związku z art. 126 k.p.a.

Termin utraty mocy postanowienia, wymieniony w art. 50 ust. 4 p.b., ma także charakter dyscyplinujący w stosunku do organu nadzoru budowlanego. Wynika to z faktu, że postępowanie prowadzone w trybie art. 50-51 ustawy, nazywane w literaturze naprawczym, różni się istotnie od tak zwanych postępowań legalizacyjnych wymienionych w art. $48 \mathrm{i}$ art. $48 \mathrm{~b}$ p.b. O ile bowiem w ostatnich dwóch przykładach chodzi o obiekt budowlany realizowany lub zrealizowany bez wymaganej prawem decyzji albo zgłoszenia, o tyle postępowanie prowadzone w trybie art. 50-51 ustawy dotyczy innych, co do zasady, mniej istotnych naruszeń prawa, określonych $\mathrm{w}$ art. 50 ust. 1 tej ustawy. Postępowania prowadzone w trybie art. 50-51 p.b. z reguły dotyczą robót budowlanych mniej skomplikowanych technologicznie. Ponadto stopień naruszenia prawa z reguły nie jest tak istotny jak w przypadkach samowoli budowlanych, określonych w art. $48 \mathrm{i} 49 \mathrm{~b}$ p.b. Z tych zapewne względów prawodawca, ważąc argumenty przemawiające za bezwzględnym respektowaniem norm prawa budowlanego i innych przepisów, a z drugiej strony bacząc, by nie przeciągać procedury naprawczej w odniesieniu do drobniejszych naruszeń prawa w nieskończoność, ustanowił dwumiesięczny termin, obligujący organ nadzoru budowlanego do wydania rozstrzygnięcia co do istoty. Jak już bowiem wspomniałem, niewydanie w tym terminie decyzji, powoduje, że nakaz wstrzymania robót budowlanych traci moc prawną. Podkreślenia wymaga, że postanowienie o wstrzymaniu robót budowlanych na mocy art. 50 p.b. dotyczy tylko robót budowlanych realizowanych. Zakończenie robót nie daje podstaw do wydania postanowienia o ich wstrzymania.

$\mathrm{W}$ drugim z powołanych przykładów prawodawca wiąże upływ terminu $\mathrm{z}$ ustaniem kompetencji do wydania aktu administracyjnego - sprzeciwu ${ }^{32}$. Odnośnie do dochowania terminu do wniesienia sprzeciwu, o którym mowa w art. 54 p.b., w orzecznictwie sądów administracyjnych można wyodrębnić trzy poglądy: pierwszy, według którego dla dochowania terminu 21 dni nie jest wymagane doręczenie sprzeciwu organu, a o dochowaniu terminu przesądza wydanie decyzji w sprawie nawet w ostatnim dniu ${ }^{33}$; drugi - przyjmujący, że termin do wniesienia sprzeciwu jest dochowany gdy sprzeciw zostanie wydany a przesyłka zawierająca sprzeciw organu zostanie nadana $\mathrm{w}$ tym terminie w polskiej placówce operatora

${ }^{32}$ Analogiczną konstrukcję zawiera art. 54 Prawa budowlanego, w myśl którego do użytkowania obiektu budowlanego, na którego wzniesienie jest wymagane pozwolenie na budowę, można przystąpić, z zastrzeżeniem art. 55 i 57, po zawiadomieniu właściwego organu o zakończeniu budowy, jeżeli organ ten, w terminie 21 dni od dnia doręczenia zawiadomienia, nie zgłosi sprzeciwu w drodze decyzji.

33 Tak np. wyrok NSA z 18 października 2011 r., II OSK 1447/10, CBOSA. 
publicznego; trzeci pogląd stanowi, że wydanie, a także doręczenie decyzji stronie winno nastąpić w terminie $21 \mathrm{dni}^{34}$.

Na poparcie poglądu pierwszego można podnieść, iż terminy do wniesienia sprzeciwu, o których mowa w art. 54 p.b. i w art. 30 ust. 5 p.b., są terminami do załatwienia sprawy - wydania orzeczenia o sprzeciwie. Różnica między powołanymi terminami, a terminami w k.p.a. do załatwienia sprawy jest taka, że upływ terminu do załatwienia sprawy $\mathrm{w}$ powołanych przepisach prawa budowlanego skutkuje równocześnie utratą kompetencji organu do wniesienia sprzeciwu. Przyjęcie wykładni, że sprzeciw musi być doręczony adresatowi w terminie 30 lub odpowiednio 21 dni, oznaczałoby, że organ musi wysłać decyzję zawierającą sprzeciw na 14 dni przed datą jego upływu, by mieć pewność, że jego decyzja zostanie doręczona w terminie - biorąc pod uwagę niemożność doręczenia przesyłki adresatowi i konieczność zastosowanie instytucji fikcji doręczenia $\mathrm{z}$ art. 44 k.p.a.

Ponadto zasadnie zauważa się w orzecznictwie, że z art. 30 ust. 5 ustawy wynika wprost, iż zgłoszenie winno być organowi „doręczone”, sprzeciw zaś przez organ „wniesiony”. Pomiędzy terminem „wniesienie”, a „doręczenie” brak jest tożsamości pojęć. $Z$ tych też przyczyn nie można nakładać na podmiot zobowiązany innych obowiązków, czy też przypisywać stronie innych uprawnień aniżeli te, które wynikają z treści normy prawnej, o tych prawach i obowiązkach stanowiącej ${ }^{35}$.

Akceptując pogląd, iż terminy o których mowa w art. 54 p.b. i art. 30 ust. 5 p.b. mają charakter materialny, należy stwierdzić, że według wymienionych norm organ ma uprawnienie będące zarazem obowiązkiem do ukształtowania stosunku prawnego za pomocą instytucji sprzeciwu, gdy uzna, że dokonane przez inwestora zgłoszenie jest niezgodne z prawem. Terminy wymienione w art. 54 i 30 ust. 5 są terminami materialnymi, ich upływ powoduje bowiem utratę kompetencji do wydania decyzji.

\section{Zakończenie}

Rozróżnienie terminów prawa materialnego od terminów prawa procesowego nie zawsze jest oczywiste. Z pewnością dla tego rozróżnienia nie jest wystarczające kryterium skorzystania z kompetencji przez organ do ukształtowania prawa $\mathrm{w}$ drodze decyzji administracyjnej. Sama kompetencja do ukształtowania prawa bądź obowiązku w formie aktu administracyjnego w określonym terminie wskazuje jedynie na zakres i charakter obowiązku organu administracji publicznej. W rozróżnieniu terminów do zajęcia stanowiska przez organy administracji publicznej istotne znaczenie ma charakter aktu lub czynności, której termin do-

${ }^{34}$ Szerzej na temat poglądów judykatury i doktryny na temat istoty tych terminów por. Z. Kostka, [w:] A. Gliniecki (red.), Prawo budowlane. Komentarz, Warszawa 2012.

35 Por. na przykład wyrok NSA z 13 września 2011, II OSK LEX nr 965177. 
tyczy. Wydaje się, że ustanowienie terminu materialnego jako swoistej gwarancji dla podmiotów administrowanych jest wskazane w przypadkach potwierdzenia uprawnienia podmiotu administrowanego, gdy milczenie organu według przepisów prawa oznacza zgodę na przyznanie, ukształtowanie czy zachowania prawa. Wówczas odmowa udzielenia tej zgody w formie decyzji może być obwarowana terminem, w którym organ może i powinien w przypadku naruszenia prawa skutecznie zakwestionować zamiar skorzystania $\mathrm{z}$ uprawnienia przez podmiot $\mathrm{w}$ sposób niedozwolony. Analogicznie co do charakteru terminu, w którym organ może wyrazić sprzeciw wobec zgłoszenia z zamiaru korzystania z określonego uprawnienia, wypowiada się judykatura na gruncie innych ustaw. Wskazać tu chociażby można termin do wniesienia sprzeciwu przez Prezesa Urzędu Komunikacji Elektronicznej przewidziany w art. 48 ust. 2 ustawy Prawo telekomunikacyjne ${ }^{36}$ czy wniesienie sprzeciwu przez Ministra Sprawiedliwości od wpisu na listę aplikantów adwokackich czy listę adwokatów ${ }^{37}$. Wspomniane przeze mnie terminy, uznane za materialne, są więc terminami gwarantującymi niektórym stronom postępowania, że po ich upływie organ administracji budowlanej nie może już skorzystać z kompetencji do zmiany ich sytuacji prawnej.

Przepisy prawa budowlanego nie zawierają reguł obliczania terminów prawa materialnego, tak jak na przykład kodeks cywilny reguluje sposób obliczania terminów przedawnienia ${ }^{38}$. Wspomnieć wypada, że do obliczania terminów prawa materialnego nie mogą mieć zastosowania przepisy kodeksu postępowania administracyjnego o terminach, chyba że z ustawy wynika odesłanie do tych przepisów.

Jeśli chodzi o sposób obliczania terminów materialnych na gruncie prawa budowlanego opowiadam się za przyjęciem stanowiska, że termin ten jest zachowany, jeśli organ wyda w nim decyzję administracyjną, natomiast data doręczenia

${ }^{36}$ Art. 48 ust. 2 ustawy z dnia 16 lipca 2004 r. Prawo telekomunikacyjne (Dz. U. nr 171, poz. 1800 ze zm) stanowi: „Prezes UKE, w drodze decyzji, w terminie 30 dni od dnia przedłożenia projektu cennika, regulaminu świadczenia usług lub ich zmiany, może zgłosić sprzeciw, jeżeli projekt cennika lub regulaminu jest sprzeczny z decyzjami, o których mowa w art. 46 ust. 2 i art. 47 ust. 1, lub z przepisami niniejszej ustawy i zobowiązać przedsiębiorcę telekomunikacyjnego do przedstawienia poprawionego cennika lub regulaminu, w części objętej sprzeciwem”.

37 Art. 69a ust. 1 ustawy z 26 maja 1982 r. Prawo o adwokaturze (tekst jedn. Dz. U. z 2009 r., nr 146, poz. 1188 ze zm) stanowi: „Wpis na listę adwokatów lub aplikantów adwokackich uważa się za dokonany, jeżeli Minister Sprawiedliwości nie podpisze sprzeciwu od wpisu w terminie 30 dni od dnia doręczenia uchwały wraz z aktami osobowymi kandydata. W przypadku, o którym mowa $\mathrm{w}$ art. 69 ust. 2, bieg terminu liczy się wówczas od dnia ponownego doręczenia uchwały wraz z aktami osobowymi. Minister Sprawiedliwości wyraża sprzeciw w formie decyzji administracyjnej”. Analogiczne rozwiązanie zawiera ustawa o radcach prawnych.

${ }^{38} \mathrm{Na}$ gruncie prawa cywilnego art. $120 \S 1$ k.c. bieg przedawnienia rozpoczyna się od dnia, w którym roszczenie stało się wymagalne. Jeżeli wymagalność roszczenia zależy od podjęcia określonej czynności przez uprawnionego, bieg terminu rozpoczyna się od dnia, w którym roszczenie stałoby się wymagalne, gdyby uprawniony podjął czynność w najwcześniej możliwym terminie.§ 2. Bieg przedawnienia roszczeń o zaniechanie rozpoczyna się od dnia, w którym ten, przeciwko komu roszczenie przysługuje, nie zastosował się do treści roszczenia. 
decyzji organu nie ma znaczenia dla zachowania tego terminu. Z punktu widzenia celu regulacji nie znajduję uzasadnienia, by przyjąć stanowisko, że termin jest dochowany jedynie wówczas, gdy decyzja organu zostanie doręczona stronie przed upływem tego terminu ${ }^{39}$. Takie rozumienie powoływanych przepisów jest niezgodne z wykładnią literalną, systemową i funkcjonalną. Regułą wynikającą z przepisów k.p.a. jest miesięczny termin do załatwienia sprawy wymagającej przeprowadzenia postępowania wyjaśniającego - art. $35 \S 3$ k.p.a. Biorąc pod uwagę cel i przedmiot regulacji, nie znajduję uzasadnienia ku temu, by w istocie tak znacząco skracać te terminy w porównaniu do terminu miesięcznego do załatwienia sprawy wymagającej przeprowadzenia postępowania wyjaśniającego - przewidzianego w art. 35 § 3 k.p.a. Szybkie podejmowanie działań organów administracji w procesie budowlanym jest niewątpliwie pożądane. Nie może jednak odbywać się kosztem ograniczenia kompetencji organu w zakresie oceny zgodności z prawem działania podmiotu administrowanego.

Podjęcie przez organ administracji budowlanej decyzji ${ }^{40}$ przerywa bieg terminu materialnego, o ile został on przez organ dochowany, i jednocześnie uruchamia termin procesowy do wniesienia środka zaskarżenia przez strony od wydanej decyzji. Zatem akt organu administracji budowlanej powoduje dwojakie konsekwencje: zanegowanie uprawnienia ${ }^{41}$ albo nałożenie obowiązku ${ }^{42}$ i jednocześnie uruchomienie postępowania instancyjnego.

Omawianym terminom materialnym $\mathrm{w}$ prawie budowlanym można przypisać funkcje: ochroną, dyscyplinującą i stabilizacyjną. Jak już wspominałem, funkcja ochronna terminów materialnych przejawia się w tym, że upływ tego terminu stanowi gwarancję dla stron postępowania administracyjnego, iż z upływem tego termin organ nie może zgodnie z prawem zmienić ich sytuacji prawnej. Upływ terminu materialnego $\mathrm{w}$ jakimś sensie petryfikuje sytuację prawną podmiotów procesu budowlanego. Z kolei funkcja dyscyplinująca terminów materialnych stanowi bodziec dla organów administracji budowlanej do skorzystania ze swoich kompetencji władczych, w przypadku dostrzeżenia naruszenia prawa, pod rygorem ich utraty z uwagi właśnie na upływ czasu. Natomiast funkcja stabilizująca polega na ochronie status quo inwestorów w procesie budowlanym poprzez to, że nieskorzystanie przez organ z kompetencji w terminie prawem przewidzianym legitymizuje w jakimś zakresie wykonane roboty budowlane.

${ }^{39}$ Muszę wyjaśnić, że w komentarzu mojego pióra do art. 54 p.b. pod red. M. Wierzbowskiego i A. Filipowicz-Plucińskiej (tekst w druku), stwierdzam, że sprzeciw wyrażany w trybie art. 54 tej ustawy jest skuteczny, o ile zostanie doręczony stronie przed upływem 21 dni. Jest to pogląd wyrażany przez większość autorów tego komentarza.

${ }^{40}$ Art. 30 ust. 5, art. 54 ustawy; albo decyzji o której mowa w art. 50 ust. 4 ustawy.

${ }^{41}$ Art. 30 ust. 5, art. 54 ustawy.

42 Wydanie decyzji o której mowa w art. 50a pkt 2 albo w art. 51 ust. 1. 